\title{
MODELLING DEER-WOODLAND DYNAMICS ON DEVILS TOWER NATIONAL MONUMENT
}

\author{
EVELYN H. MERRILL $\bullet$ GREG W. MCDANIEL \\ DEPARTMENT OF ZOOLOGY AND PHYSIOLOGY \\ Michael COUghenour $\bullet$ NATURAL RESOURCE ECOLOGY LAB \\ COLORADO STATE UNIVERSITY • FORT COLLINS
}

We are adapting the spatially explicit, process-oriented model Savanna developed by M. B. Coughenour to Devils Tower National Monument (DTNM). The model will be used to describe the woodland-deer dynamics within a short time-frame ( $<30$ years) under several management scenarios. We use data on weather, vegetation standing crops, deer distributions and population information collected during 1991-1992 as initial conditions to the model.

The savanna model is composed of hydrologic, plant biomass production, plant population dynamics, ungulate herbivory, ungulate spatial distribution, population dynamics and culling submodels.

The model has a hierarchical, 3-staged landscape. DTNM landscape has been divided into a grid of $25 \times 25100-\mathrm{m}$ grid cells. Within the grid cells, there are "subareas" which correspond to fixed distributions of physical conditions like soils and topography. Within the subareas, the model simulates vegetation patches or "facets" defined as herbaceous plants, shrubs and trees. The facet locations are not modeled within the grid but the facet cover (\%) is a dynamic outcome of the vegetation growth and mortality. Initial biomass within each cell was based on the weighted average biomass of the cover types found in each cell.

Base station data of monthly precipitation and temperature for the period 1972-1993 was originally used to calibrate the model. Predictions (future scenarios) will be based on randomly generated weather data. A snowmelt submodel simulates snow water content and depth and snow crusting which is stochastically related to temperature. The water budget submodel simulates soil moisture dynamics on each patch type on each grid cell based on soil maps in conjunction with properties of soil. The net primary production (NPP) submodel is affected by water, light, temperature, nitrogen, and herbivory. The NPP model is linked to the water budget through transpiration and plant water use efficiency. Light extinction through the canopy follows an exponential decay function, dependant on leaf area indices. Nitrogen uptake is modelled and losses are caused by herbivory and tissue mortality. The herbivory submodel simulates ungulate foraging determined by diet selection, forage abundance and quality and snow cover. Ungulate spatial distribution is based on HSI models developed on habitat use data from radio-collared deer. Population dynamics of deer is a stage-structured model with 5 age-sex classes where birth and death rates are based on conditions modified in the ungulate energy balance submodel.

Progress to date includes the development of the GIS-based input maps, initial parameterization of the model, and initial runs of seasonal forage dynamics. Within the next year, we hope to have parameterized the ungulate spatial distribution, herbivory, deer population, and deer culling models. We do not expect to have the model completed for at least another 1-2 years given the limited financial support available to us. 